\title{
RELATIONSHIPS BETWEEN BARK BEETLE DIVERSITY AND HABITAT CHARACTERISTICS IN PINE FORESTS OF SOUTH MARMARA, TURKEY
}

\author{
ACER, S. ${ }^{1}$ - ARSLANGÜNDOĞDU, Z. ${ }^{1}-$ HIZAL, E. ${ }^{1 *}-$ KUMBAŞLI, M. ${ }^{2}$

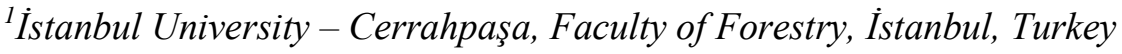 \\ ${ }^{2}$ Bolu Abant İzet Baysal University, Wildlife Research Center, Bolu, Turkey \\ ${ }^{*}$ Corresponding author \\ e-mail: hizal@istanbul.edu.tr
}

(Received $31^{\text {st }}$ Jul 2020; accepted $19^{\text {th }}$ Nov 2020)

\begin{abstract}
The bark beetles are of particular importance in the evolution and biodiversity of forest stands. To contribute to the knowledge on the biodiversity and ecology of bark beetles on pine species, we performed this research in South Marmara, Turkey. During 2014, Scolytinae species were obtained from baiting logs, which were $1.5 \mathrm{~m}$ long, and $0.2 \mathrm{~m}$ in diameter located at 8 sites in total in the research area. In total, 1100 individuals were collected representing 6 tribes, 11 genera, and 24 species. Orthotomicus erosus was the most abundant species and occurred in all areas. Our study demonstrated that black pine is associated with high diversity of beetles while brutian pine is correlated with high abundance of Scolytinae. In addition, stone pine has lowest diversity and abundance of bark beetles. Pinus brutia, which showed strong correlation with temperature, had relationship with $O$. erosus and $P$. pennidens. Pinus nigra showed a strong correlation with altitude, additionally it had relationship with I. sexdentatus. Our results indicate that these abiotic factors affect the composition and the number of bark beetles.
\end{abstract}

Keywords: Pinus spp., Scolytinae species, biodiversity, ecological relationships, dispersal

\section{Introduction}

The bark beetles are of particular importance in the evolution and biodiversity of forest stands. During undisturbed forest succession, they commonly feed upon and kill the excess plants in the stand. The vast majority of bark beetles are saprophagous, strictly breeding in dead trees or tree parts. Tree-killing bark beetles, while relatively few in number, can have profound ecological effects, including impacts on species composition, age structure, density, woody debris inputs, and even global carbon balance (Bright and Stark, 1973; Kurz et al., 2008; Lindgren and Raffa, 2013). In addition to their ecological roles, some bark beetles compete with humans for valued plants and plant products, and so are significant forest and agricultural pests (Raffa et al., 2015). Like most insects, bark beetles have high reproductive potentials that provide the capability to undergo rapid, exponential population increase (Økland and Bjørnstad, 2006; Marini et al., 2013). At outbreak population levels, beetles can cause extensive tree mortality altering forest structure, reducing fiber production capacity, and diminishing stand aesthetics (Cole and McGregor, 1988; Fiddler et al., 1989; Cochran and Barrett, 1998). Increases in surface fuel loadings also follow bark beetle-caused mortality (Jenkins et al., 2008). In this case, these species cause substantial socioeconomic losses, and at times necessitate management responses (Klutsch et al., 2009; Raffa et al., 2015). In Europe, there are relatively few bark beetle species that are regarded as serious pests, the majority are secondary pests feeding and reproducing in dead and dying trees, and they rarely cause significant damage or losses, especially to 
live trees (Grégoire and Evans, 2004; Sauvard, 2004). Secondary bark beetles have been observed attacking healthy trees far more frequently, presumably in response to changing climate patterns, particularly increased drought periods (Gregoire et al., 2001; Kuhnholz et al., 2001). However, coniferous monocultures are generally regarded as being poor structurally, lacking in biodiversity and highly susceptible to pest, pathogens and climate change (Koricheva et al., 2006; Jactel and Brockerhoff, 2007; Brockerhoff et al., 2008).

Environmental variables play a major role in shaping the bark beetles' diversity and dispersal. Temperature limits insect populations and regulates their distribution. Interactions between bark beetles and temperature are highly complex and include varying patterns of perpetuation, survival threshold, facultative diapause, and adaptation to harsh cold (Heliövaara and Peltonen, 1999). Air humidity acts on behave of bark beetles such as host selection (Heliövaara and Peltonen, 1999), flight dispersal (Franklin and Grégoire, 1999), and overwintering (Koštál et al., 2011).

Dispersal by flight is obligatory for bark beetles in the subfamily Scolytinae. Adult bark beetles must leave the natal host and fly to seek new hosts for brood production (Jones et al., 2019). Wind speed and direction can have a large impact on the flight of small insects such as bark beetles. Bark beetles can be dispersed over quite a long distance by wind (Byers, 2000). Wind can influence the distance that bark beetles fly, the energy used during flight, and the direction in which beetles disperse. The average dispersal of most bark beetles is less than $5 \mathrm{~km}$ while long - distance dispersal can reach more than $100 \mathrm{~km}$ per day in flight aided by the wind (Jones et al., 2019).

In general, a greater diversity of insects is found at the lower or intermediate altitudes where conditions are less extreme and many species. Altitude has an effect limiting the diversity and distribution of bark beetles (Rubin-Aguirre et al., 2015).

The composition and richness of species assemblages also strongly influence ecosystem functioning and stability. The conservation of insect diversity is therefore a topic of global importance (Zou et al., 2011; Hlásny et al., 2019). While there were numerous studies in Europe (Jakus, 1998; Peltonen et al., 1998; Weslien and Schroeder, 1999; Kalapanida-Kantartzi et al., 2010; Foit, 2015), only a few researchers (Sar1kaya and Yıldırım, 2011; İbiş and Sarıkaya, 2012) investigated the composition and diversity of bark beetle communities under different environmental conditions in Turkey. It is necessary to research forest communities across the country and to observe which insects are present in a particular area. In this way, when a particular insect population begins to grow, researchers will be able to predict the extent of the damage and what control measures to use. In this study, the bark beetle species on pines were investigated at different stands in the South Marmara of Turkey. Brutian pine (Pinus brutia Ten.), black pine ( $P$. nigra Arnold) and stone pine ( $P$. pinea L.) are the main species of pine forests of the area. This section is the natural spreading boundary in the north for the brutian pine. In addition, it is an area where valuable black pine forests in Turkey. Stone pine in the area serves multi-functional purposes such as pine nut, timber, and landscape planning. If we want to perform holistic forest management in such an important area, it is necessary to better understand the biodiversity and ecology of bark beetles in relation to their habitat characteristics. The aim of this research is to contribute to the knowledge about biodiversity and ecology of bark beetles. 


\section{Materials and Methods}

Our research was carried out in Çanakkale and Balıkesir provinces in the south part of Marmara Region (Fig. 1). The area has coastal in the Marmara and Aegean Region of Turkey and hosts the Strait of Çanakkale that one of the two straits of Turkey. The climate in the region shows characteristic transition climate of the Mediterranean - the Black Sea (Doğukan et al., 2008). Average annual temperature is $14.8^{\circ} \mathrm{C}$ with the maximum summer temperature $30.6^{\circ} \mathrm{C}$ and minimum winter temperature $2.7^{\circ} \mathrm{C}$. Average annual rainfall is approximately $615.4 \mathrm{~mm}$ (TSMS, 1998). The prevailing soil type is inceptisol soil according to American classification (Efe, 1999). Approximately $43 \%$ of the area is covered with forests while $74 \%$ of forest areas in the region are constituted by pine species (Anonymus, 2006; Karagöz and Demirci, 2015) (Fig. 1).

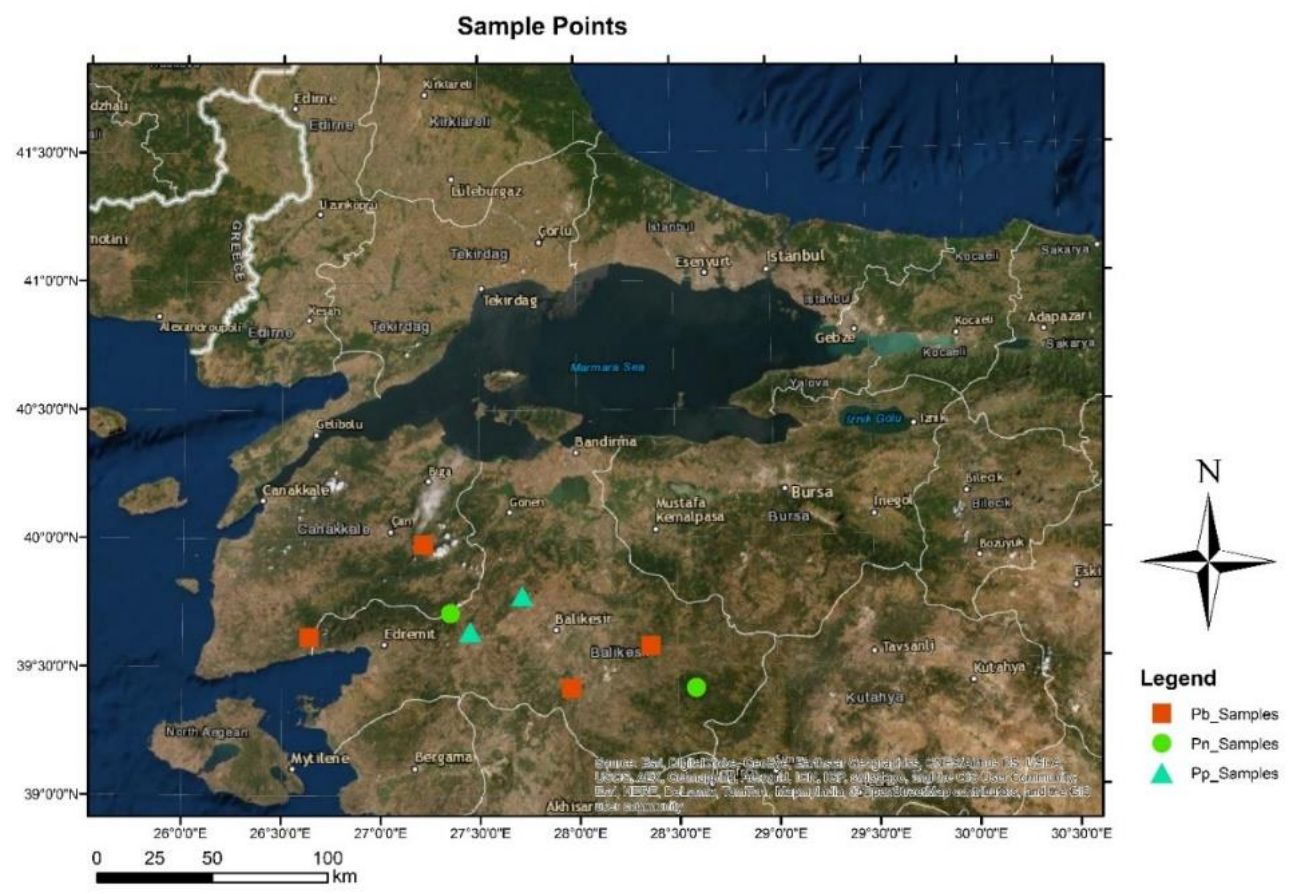

Figure 1. Sampling points in the field study conducted on pines in South Marmara in 2014

During 2014, Scolytinae species were collected from baiting logs in totally 8 sites in research area; 4 different pure stands of $P$. brutia $(\mathrm{Pb}-1$ and 4 mature stands, $\mathrm{Pb}-2$ and 3 young stands), 2 different pure mature stands of P. nigra (Pn-1 and 2) different pure young stands of $P$. pinea (Pp-1 and 2). Sampling points, altitudes, and geographical coordinates were also noted (Table 1) and pointed out on a map by ARCGIS 10.2 (Fig. 1) (ESRI, 2014). In February 2014, baiting logs, $1.5 \mathrm{~m}$ long and $0.2 \mathrm{~m}$ in diameter (bark thickness about $2 \mathrm{~cm}$ ) were set in each stand, using the technique described by Tribe (1992). Traps were checked every twenty days and three logs at each site were inspected for the presence of beetle entrance holes. All beetles brought to the laboratory were morphologically identified with a LEICA S8APO stereomicroscope to determine with several taxonomic keys that provide taxonomic characteristics located in the pronotum, scutellum, elytra, metapisternum and antennal funiculum, etc. (Grüne, 1979; Wood, 1982; Selmi, 1998; Lompe, 2002; Benisch, 2007; Jordal and Knízek, 2007). 
Table 1. Sampling points characteristics

\begin{tabular}{|c|c|c|c|c|c|c|}
\hline $\begin{array}{c}\text { Sampling } \\
\text { Point }\end{array}$ & $\begin{array}{c}\text { Geograpgical } \\
\text { position }\end{array}$ & $\begin{array}{c}\text { Altitude } \\
\text { (m) }\end{array}$ & $\begin{array}{c}\text { Tree species / } \\
\text { stand type }\end{array}$ & ${ }^{* * *}$ Soil type & $\begin{array}{c}\text { Temperature } \\
\left({ }^{\circ} \mathbf{C}\right)\end{array}$ & $\begin{array}{c}{ }^{* * * *} \text { Humidity } \\
(\%)\end{array}$ \\
\hline Pb-1 & $\begin{array}{l}39^{\circ} 34^{\prime} 46.6^{\prime \prime} \mathrm{N} \\
28^{\circ} 21^{\prime} 42.1^{\prime \prime} \mathrm{E}\end{array}$ & 508 & P. brutia / c & $\begin{array}{l}\text { Orthic } \\
\text { luvisol }\end{array}$ & 16,3 & 69,8 \\
\hline $\mathbf{P b}-2$ & $\begin{array}{l}39^{\circ} 24^{\prime} 57.7^{\prime \prime} \mathrm{N} \\
27^{\circ} 57^{\prime} 44.8^{\prime \prime} \mathrm{E}\end{array}$ & 442 & P. brutia / c & $\begin{array}{c}\text { Eutric } \\
\text { cambisol }\end{array}$ & 18,1 & 69,3 \\
\hline $\mathbf{P b}-3$ & $\begin{array}{l}39^{\circ} 37^{\prime} 02.6^{\prime \prime} \mathrm{N} \\
26^{\circ} 38^{\prime} 19.3^{\prime \prime} \mathrm{E}\end{array}$ & 557 & P. brutia / c & $\begin{array}{c}\text { Eutric } \\
\text { cambisol }\end{array}$ & 18,6 & 71,1 \\
\hline $\mathrm{Pb}-4$ & $\begin{array}{l}39^{\circ} 58^{\prime} 41.6^{\prime \prime N} \\
27^{\circ} 13^{\prime} 0.6^{\prime \prime} \mathrm{E}\end{array}$ & 380 & P. brutia / c & $\begin{array}{l}\text { Orthic } \\
\text { luvisol }\end{array}$ & 17,1 & 76,3 \\
\hline Pn-1 & $\begin{array}{l}39^{\circ} 24^{\prime} 47.9^{\prime \prime} \mathrm{N} \\
28^{\circ} 35^{\prime} 18.6^{\prime \prime} \mathrm{E}\end{array}$ & 1164 & P. nigra / c & $\begin{array}{l}\text { Orthic } \\
\text { luvisol }\end{array}$ & 16,3 & 69,8 \\
\hline Pn-2 & $\begin{array}{l}39^{\circ} 42^{\prime} 34.9^{\prime \prime} \mathrm{N} \\
27^{\circ} 21^{\prime} 09.3^{\prime \prime} \mathrm{E}\end{array}$ & 730 & P. nigra / c & $\begin{array}{c}\text { Eutric } \\
\text { cambisol }\end{array}$ & 17,6 & 73,2 \\
\hline Pp-1 & $\begin{array}{l}39^{\circ} 46^{\prime} 40.1^{\prime \prime} \mathrm{N} \\
27^{\circ} 42^{\prime} 56.3^{\prime \prime} \mathrm{E}\end{array}$ & 338 & P. pinea / b & $\begin{array}{c}\text { Eutric } \\
\text { cambisol }\end{array}$ & 15,9 & 80,9 \\
\hline Pp-2 & $\begin{array}{l}39^{\circ} 38^{\prime} 23.7^{\prime \prime N} \\
27^{\circ} 27^{\prime} 04.7^{\prime \prime} \mathrm{E}\end{array}$ & 280 & P. pinea / b & $\begin{array}{l}\text { Orthic } \\
\text { luvisol }\end{array}$ & 17,6 & 73,2 \\
\hline
\end{tabular}

"["a" (0-8 cm), "b" (9-20 cm) and "c" (21-36 cm) mean diameter at breast height (DBH)], ${ }^{* *}$ FAO Soil Map was used for soil classification (FAO, 2020), ${ }^{* * *}$ (TSMS, 1998)

Species accumulations by time and sample effort were assessed with rarefaction curves (Rodrigez et al., 2017). Species diversity was calculated by Shannon index $\left(\mathrm{H}^{\prime}\right)$ (Spellerberg and Fedor, 2003). Evenness was measured by Pielou index ( $\left.\mathrm{J}^{\prime}\right)$ (Pielou, 1969). For each area, the relative abundance of species was transformed to logarithm-10 $(\mathrm{N}+1)$ and the tabulated data from the most abundant species to the least abundant (Feinsinger, 2001). All analyzes were undertaken PAST 4.03 (Hammer et al., 2001). Species diversity results compared by overlapping of confidence intervals obtained in software ANAFAU (Moraes et al., 2003).

The air temperature, air humidity, and wind speed employed data represent the study period averages obtained from 7 automatic weather station (AWS) (18082, 18434, $17158,18085,17700,18432,18436)$ that are the nearest to each sampling point in the area (Fig. 2) (TSMS, 1998). Altitude data were taken from each sampling point using GPS.

To evaluate the effect of environmental variables on species composition and abundance in the 8 sampling area, Canonical Correspondence Analysis (CCA) was performed. Eigenvalues representing the contribution of each classification axis to the explanation of the change in data were used in CCA. There is one eigenvalue for each ordination axis, and the size for an axis is a direct indication of the importance of that axis in variation within the data set (Chung et al., 2001). The importance of individual variables for the CCA ordination model was assessed by the Monte Carlo test and forward selection. In this process, the explanatory environmental variables are added to a null model of a fully stochastic dataset according to their contribution to the explained variability. The significance of increase of the fit after adding a variable is tested by a Monte Carlo permutation test with 999 replicates. 


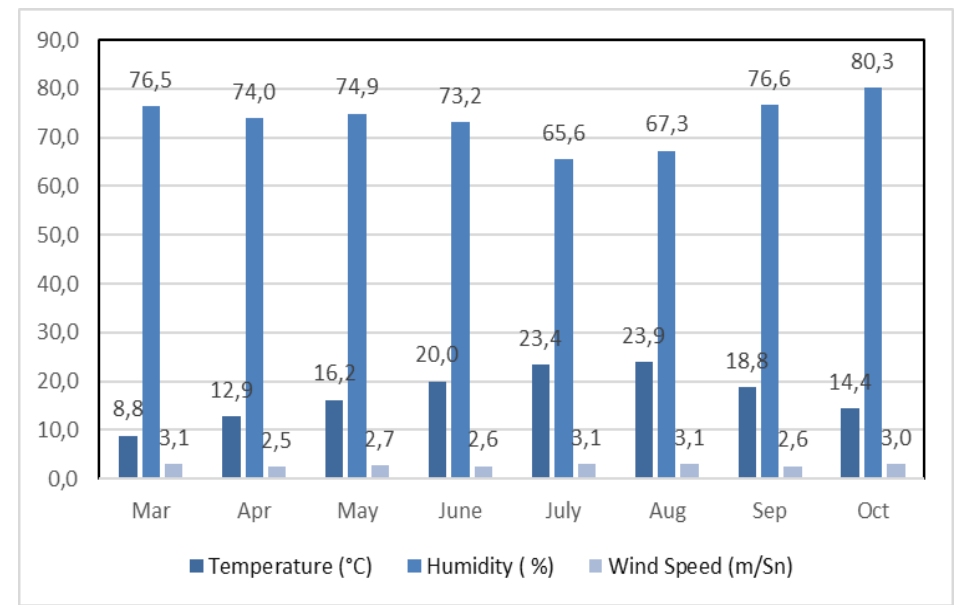

Figure 2. Air temperature, humidity and wind speed during the experiment in research area

Species with less than five individuals were excluded from the analysis and any remaining species or sample outliers were removed (due to their misleading effect on the analysis, and allowing species association patterns to be displayed more clearly), leaving a total of 16 species (98.7\% of individuals) included in the analysis. Species abundance was studied by converting to logarithm-10 $(N+1)$, (Hulcr et al., 2008; Mullen et al., 2008; Foit, 2015; Zhang et al., 2017). All analyzes were undertaken PAST 4.03 (Hammer et al., 2001).

\section{Results}

In total, 1100 individuals were collected representing 6 tribes, 11 genera, and 24 species. The most abundant tribe was Ipini (78.18\% - 9 species), followed by Tomicini (12.73\% - 5 species), Hylastini (5.18\% - 3 species), Crypturgini (3.18\% - 4 species), Polygraphini (0.55\% - 1 species), and Xyleborini (0.18\% - 2 species) (Table 2). Ipini had the highest abundance (860 individuals) and the greatest richness ( 9 species). The rarefaction curves for some sites have not approached an asymptote $(\mathrm{Pb}-2$ and $\mathrm{Pp}-1)$ indicating efficiency in sampling species of Scolytinae beetles in this study (Fig. 3).

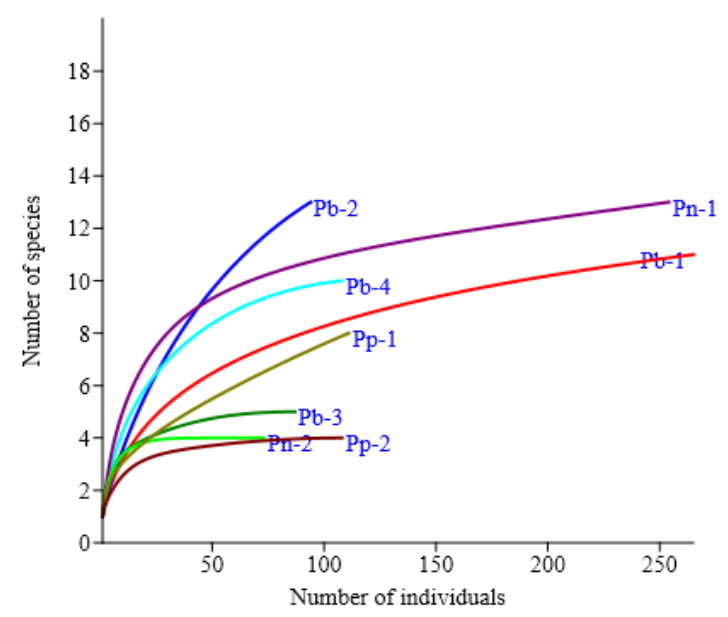

Figure 3. Individual based species accumulation curves 
Table 2. Species of subfamily Scolytinae collected in eight sites at research area

\begin{tabular}{|c|c|c|c|c|c|c|c|c|c|c|}
\hline & Pb 1 & $\mathbf{P b} 2$ & $\mathbf{P b} 3$ & $\mathbf{P b} 4$ & Pn-1 & Pn-2 & Pp-1 & Pp-2 & Total & $\%$ \\
\hline Tribe: Crypturgini & & & & & & & & & & \\
\hline Crypturgus cinereus & 1 & & & 5 & 14 & & & & 20 & 1,82 \\
\hline Crypturgus hispidulus & & & & 2 & 1 & & & & 3 & 0,27 \\
\hline Crypturgus numidicus & 5 & & & 5 & & & & & 10 & 0,91 \\
\hline Crypturgus pusillus & 1 & & & 1 & & & & & 2 & 0,18 \\
\hline Tribe: Hylastini & & & & & & & & & & \\
\hline Hylastes angstatus & 3 & 1 & & 15 & 4 & & & & 23 & 2,09 \\
\hline Hylastes linearis & & 2 & & & & & & & 2 & 0,18 \\
\hline Hylastes opacus & 14 & & & & 11 & 7 & & & 32 & 2,91 \\
\hline Tribe: Ipini & & & & & & & & & & \\
\hline Ips sexdentatus & 35 & 2 & 3 & & 86 & 35 & & & 161 & 14,6 \\
\hline Orthotomicus & 187 & 67 & 42 & 58 & 70 & 23 & 41 & 83 & 571 & 51,9 \\
\hline Orthotomicus long & & 2 & & & 16 & & & & 18 & 1,64 \\
\hline Pityogenes bidentatus & & 1 & & & & & & & 1 & 0,09 \\
\hline Pityogenes bistridentatus & & & & & 21 & & & & 21 & 1,91 \\
\hline Pityogenes cal & & & & & & & 2 & & 2 & 0,18 \\
\hline Pityogenes calcographus & & 1 & & & & & 8 & & 9 & 0,82 \\
\hline Pityogenes pennidens & 12 & & 21 & 15 & 19 & 8 & & & 75 & 6,82 \\
\hline $\begin{array}{l}\text { Pityokteines spinidens } \\
\text { Tribe: Polygraphini }\end{array}$ & & & & & 1 & & 1 & & 2 & 0,18 \\
\hline $\begin{array}{c}\text { Carphoborus henscheli } \\
\text { Tribe: Tomicini }\end{array}$ & & & 2 & 2 & 1 & & 1 & & 6 & 0,55 \\
\hline Hylurgus lignip & 4 & 6 & & 2 & & & 1 & 11 & 24 & 2,18 \\
\hline Hylurgus micklitzi & 2 & 2 & & 3 & & & 1 & 2 & 10 & 0,91 \\
\hline Tomicus destruens & & 5 & 19 & & & & & & 24 & 2,18 \\
\hline Tomicus minor & & 3 & & & 4 & & & & 7 & 0,64 \\
\hline $\begin{array}{l}\text { Tomicus piniperda } \\
\text { Tribe: } \text { Xvleborini }\end{array}$ & & 1 & & & 6 & & 56 & 12 & 75 & 6,82 \\
\hline Xyleborus eurygraphus & & 1 & & & & & & & 1 & 0,09 \\
\hline Xyleborinus sax & 1 & & & & & & & & 1 & 0,09 \\
\hline Numbe & 265 & 94 & 87 & 108 & 254 & 73 & 111 & 108 & 1100 & \\
\hline Numbe & 11 & 13 & 5 & 10 & 13 & 4 & 8 & 4 & & \\
\hline Shannon D & 1,098 & 1,252 & 1,230 & 1,531 & 1,876 & 1,183 & 1,145 & 0,753 & & \\
\hline Equitability Index $\left(\mathbf{J}^{\prime}\right)$ & 0,475 & 0,488 & 0,764 & 0,665 & 0,731 & 0,853 & 0,550 & 0,543 & & \\
\hline
\end{tabular}

Orthotomicus Ferrari was the most abundant (53.55\% of individuals) genus, represented by two species: $O$. erosus (Wollaston) and $O$. longicollis (Gyllenhal). $O$. erosus was the most abundant species in this study (571 individuals $-51.91 \%$ ). Ips De Geer were the second highest in abundance (161 individuals - 14.64\%) and represented by only one species is $I$. sexdentatus Börner. The third most abundant genus was Pityogenes Bedel (9.82\% of 108 individuals -), represented by five species and most abundant species $P$. pennidens (Reitter) (75 individuals $-6.82 \%$ ). This ranking was followed by Tomicus Latreille (106 individuals - 9.64\%), Hylastes Erichson (57 individuals - 5.8\%), Crypturgus Erichson (35 individuals - $3.8 \%$ ), Hylurgus Latreille (34 individuals - 3.09\%), Carphoborus Eichhoff (6 individuals - $0.552 \%$ ), Pityokteines (2 individuals $-0.18 \%)$, Xyleborinus Reitter (1 individual - 0.09\%) and Xyleborus Eichhoff (1 individual - 0.09\%) (Table 2).

$\mathrm{Pb}-1$ presented the highest abundance with 265 individuals (23.1\% of the sample) distributed in 11 species followed by Pn-1 (P. nigra stand) with 254 individuals $(22.1 \%$ of the sample) of 13 species (Fig. 4). In this study, 21 species were determined in $P$. brutia stands, 13 in P. nigra and 8 in P. pinea. 


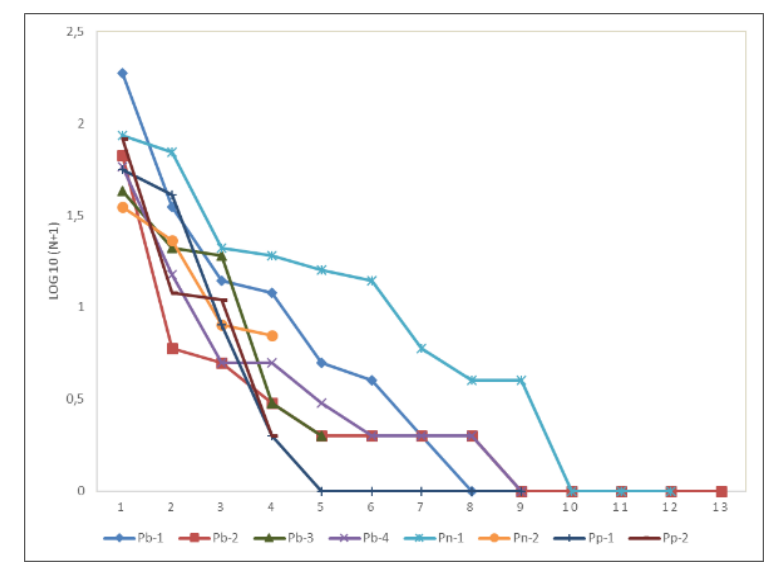

Figure 4. Distribution of abundance $(L N)$ in logarithm base $10(N+1)$ of the subfamily species Scolytinae collected in eight sites at research area. The numerical code corresponding to each species showed in Table 1

Pn-1 was the area representing the highest value for Shannon index $\left(\mathrm{H}^{\prime}=1.876\right)$ differing statistically from other areas. $\mathrm{Pb}-2$ showed the lowest values for this index (Table 2) (Fig. 5). Regarding evenness, Pn-2 presented the highest values $\left(\mathrm{J}^{\prime}=0.853\right)$. $O$. erosus occurred in all areas. $O$. erosus was the most abundant species followed by $I$. sexdentatus, $P$. pennidens and $T$. piniperda. In addition, these species were the indicator species and together with $H$. angustatus, $C$. henscheli, $H$. ligniperda and $H$. micklitzi were constant species of the study. While $O$. erosus had the highest number of individuals in brutia pine stands, I. sexdentatus had the highest number of individuals on black pine and $T$. piniperda on stone pine.

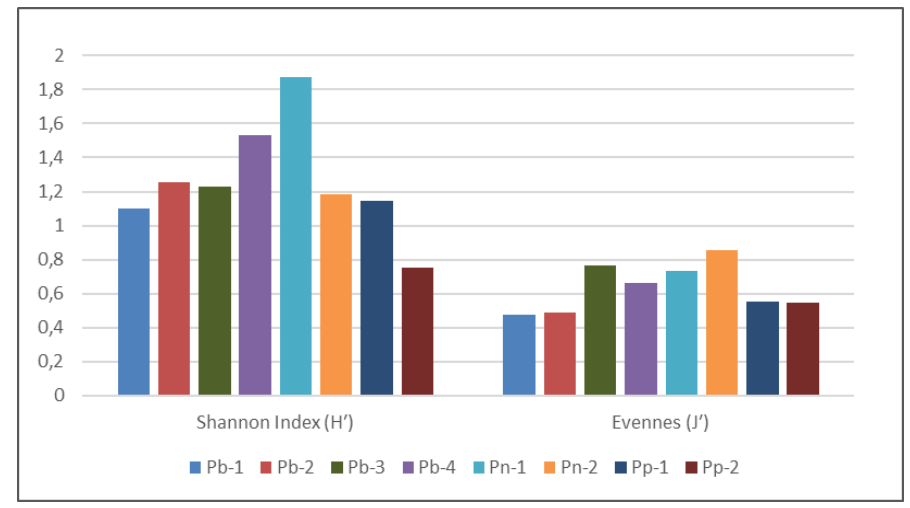

Figure 5. Bar diagrams of Shannon-Wiener Diversity Index $\left(H^{\prime}\right)$ and Equitability $\left(J^{\prime}\right)$ for eight sites, from the cumulative data of the traps in the study period

CCA was performed to determine the ecological relationship between 16 scolytinae species and 4 environmental variables (temperature, humidity, wind speed, altitude). In the ordination diagram, when the species and environmental arrows point in the same direction, species are predicted to have a large positive correlation with the environmental variable, whereas if the species and environmental arrows point in opposite directions, species are predicted to have a large negative correlation with the environmental variable. According to CCA, temperature, and humidity strongly 
correlated with the first canonical axis that explains $67.2 \%$ of the variability in the species occurrence, whereas wind speed and altitude showed a strong correlation with the second axis that explains $23.2 \%$ of total variations (Table 3). Brutian pine sites (except $\mathrm{Pb}-4)$ and one stone pine site $(\mathrm{Pp}-2)$ distributed on the right side of the diagram and showed a stronger association with temperature and humidity. Black pine sites (Pn1 and 2) and another stone pine site (Pp-1) were located on the left side of the diagram and indicated correlations with wind speed, and altitude. O. erosus and $P$. pennidens (among the most abundant species) located on the left side of the diagram and showed a positive correlation with temperature, while they were negatively related to humidity, wind speed and altitude. In addition, $T$. destruens, $T$. minor, $H$. opacus, and $H$. ligniperda had positive relation with temperature. Abundant species on the right side of the diagram, I. sexdentatus showed a positive correlation with altitude, whereas $T$. piniperda had a positively relationship to wind speed. In the same way, C. cinereus, $O$. longicollis, and H. angustatus had a positive correlation with altitude (Fig. O).

Table 3. Canonical correspondence analysis results of environmental variables on bark beetle species

\begin{tabular}{l|c|c|c}
\hline & Axis 1 & Axis 2 & Axis 3 \\
\hline Eigenvalues & 0.038529 & 0.011768 & 0.0030908 \\
Environment-related variation of Species \% & 72.2 & 22.0 & 5,8 \\
Temperature & -0.672487 & 0.25891 & 0.328465 \\
Humidity & 0.582047 & 0.40004 & -0.32935 \\
Wind speed & 0.330915 & 0.843203 & 0.123681 \\
Altitude & 0.508022 & -0.582722 & 0.402564 \\
\hline
\end{tabular}

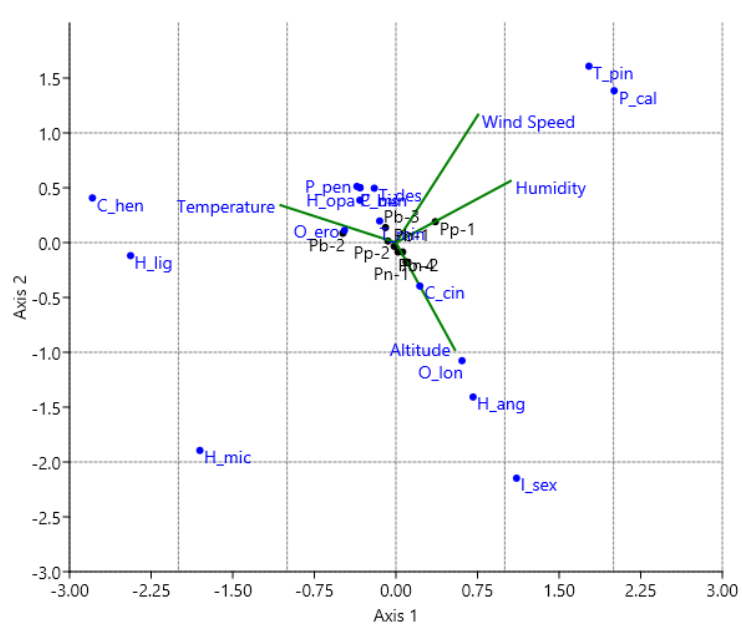

Figure 6. Canonical correspondence analysis (CCA) tri-plot showing the relation between scolytinae species (14) and environmental variables (4) in South Marmara Region, Turkey. Arrow length indicates relative importance (correlation strength) towards those parameters; arrow direction indicates a positive or negative (opposite) relationship with each variables and species or sites. (Species abbreviations used: $C_{-}$cin: Crypturgus cinereus, $C_{-}$num: $C$. numidicus, $H \_a n g:$ Hylastes angustatus, $H \_o p a: H$. opacus, I_sex: Ips sexdentatus, $O \_e r o:$ Orthotomicus erosus, $O \_l o n: O$. longiscollis, $P \_b i s:$ Pityogenes bistridentatus, $P \_c a l: P$. calcographus, $P \_$pen: $P$. pennidens, $C \_$hen: Carphobours henscheli, $H_{-}$lig: Hylurgus ligniperda, H_mic: H. micklitzi, T_des: Tomicus destruens, T_min: T.minor, T_pin: T. piniperda) 


\section{Discussion}

Many studies have tended to concentrate on effective management practices have on the abundance of bark beetles and have not fully investigated the effect on diversity. This is mainly because these management practices, which usually amount to various thinning regimes, have been adopted as a means of preventing or attempting to control outbreaks of specific primary bark beetles hence maintaining or enhancing bark beetle diversity has not been an objective (Fettig et al., 2007; Williams et al., 2017). In areas where the severe impact of insects is not determined, the situation of not conducting studies on the subject is frequently encountered, especially in regions where there are no economically significant epidemics. Concerns about the impact of these organisms on the economy are often not taken seriously until significant outbreaks occur. Strategies such as saving the infested wood instead of controlling the epidemic are put forward (Ogden, 2008).

The current study demonstrated that black pine is associated with a high diversity of beetles while brutian pine is correlated high abundance of Scolytinae. In addition, stone pine has the lowest diversity and abundance of bark beetles. The Shannon-Weiner index $\left(\mathrm{H}^{\prime}\right)$ and Equitability Index $(\mathrm{J})$ showed in black pine sites, despite the lower number of individuals, demonstrated higher biodiversity $\left(\mathrm{H}^{\prime}=1.876\right)$, and at the same time much more even distribution of individuals among species $(\mathrm{J}=0.853)$. On the other hand, in spite of the fact that in Turkish pine sites a slightly greater number of species (Totally 21 species) and the cumulative number of individuals was observed during the study period, diversity was lower and individuals were less evenly distributed among species. In general, despite the fact that the different species composition at each sampling point and the small difference in species richness, all display nearly identical "volume" of diversity when measured by the Shannon index. In the present study, 21 species in $P$. brutia stands, 13 species in $P$. nigra stands and 8 species in $P$. pinea stands were determined. The bark beetle species number identified in this research was higher than previous studies on each three-pine species in Turkey (Dönmez, 2006; Sarıkaya and Avc1, 2011; İbiş and Sarıkaya, 2012; Y1ldız, 2012). We can say that this is an accurate reflection of the diversity in our research area.

$O$. erosus occurred in all areas and was the most abundant species. This was also in accordance with the literature (Kalapanida-Kantartzi et al., 2010; Sarıkaya and Avc1, 2011; İbiş and Sarıkaya, 2012). I. sexdentatus and P. pennidens were abundant species in this study and not detected in $P$. pinea sites. In previous studies $P$. pennidens was determined on P. pinea, while I. sexdentatus was not recorded (Selmi, 1998; Lieutier et al., 2016).

Our assessments of diversity have not reached an asymptote at two sampling points, indicating the need for further sampling to arrive at a reliable estimate of diversity. We can expect that with increased sampling, significantly more species would be found at each site. It cannot be predicted whether the increased sampling will lead to an increase or decrease in the similarity between the sites. That is because increased sampling may detect species that are both rare and localized (Rosenzweig, 1995), but equally probable is the discovery of more shared species (Hulcr et al., 2008).

In CCA analysis, the longer the arrow, the greater the confidence of the inferred correlation, either amongst environmental variables, or with the two principal ordination axes, and therefore, the greater the importance in explaining variation within the data. Species located near to or beyond the tip of the arrow are strongly positively correlated with that environmental variable (Mullen et al., 2008). In the current study, temperature 
and humidity strongly correlated with the first canonical axis that explains $67.2 \%$ of the variability in the species occurrence. It is known that interactions between bark beetles and temperature are highly complex. Beetle development rates, and sometimes the number of generations per year, increases with temperature and are expected to increase in response to climate change (Hlásny et al., 2019). O. erosus and P. pennidens (among the most abundant species) showed a strong positive correlation with temperature, while they were negatively related to humidity, wind speed, and altitude. In previous studies, the geographical distribution of $O$. erosus suggests that it is suited to relatively high temperatures. Studies of the effect of temperature upon the development of $O$. erosus led to the conclusion that $O$. erosus can develop when temperatures are as high as $36-$ $38^{\circ} \mathrm{C}$ (Mendel and Halperin, 1982; Mendel, 1983; Sarıkaya et al., 2013). Considering the different altitude, it was shown that the phenology of $O$. erosus changes inversely with the altitude (Özkazanç et al., 1985; Peltonen and Heliövaara, 1999; Sarıkaya et al., 2013). P. pennidens is also known from the eastern Mediterranean: Greece, Syria, Turkey, and the Caucasus region (Grüne, 1979; Wood and Bright, 1992; Selmi, 1998). According to our results, $P$. brutia, which showed a strong correlation with temperature, had a relationship with $O$. erosus and $P$. pennidens. Sar1kaya et al. (2013) recorded that $O$. erosus indicates that the increase in population density occurs when the average relative humidity is below $50 \%$.

Abundant species on the right side of the diagram, I. sexdentatus showed a positive correlation with altitude and wind spread. Özcan et al. (2011) stated that the number of individuals was higher in higher altitudes for I. sexdentatus on oriental spruce. Jactel (1991) reported that wind speed was positively correlated with the flight of the $I$. sexdentatus. Likewise, $C$. cinereus, $O$. longicollis and $H$. angustatus showed a positive correlation with altitude. In accordance with our results, $P$. nigra showed a strong correlation with altitude, additionally, it had a relationship with $I$. sexdentatus. $T$. piniperda, which was the other abundant species, was on the right side of the diagram and related to the stone pine site on same side of the diagram. In addition, they had correlated with wind speed. Furthermore, $T$. piniperda had the highest individual number in stone pine sites. A study on the host preferences of $T$. piniperda and $T$. destruens in Portugal revealed that both insect species preferred stone pine in the south, and Aleppo pine in the north (Vasconcelos et al., 2003). This indicates that T. piniperda may also prefer stone pine depending on the geography.

\section{Conclusion}

Insects are the most discussed species during ecosystem analyzes in terms of diversity and abundance because of their ability to complete their life cycle in a short time (usually 1 year) and to adapt quickly to environmental changes. Phytophagous insects are more used in these analyzes. On the other hand, it is known that plant groups also exhibit geographic and temporal changes. However, it takes longer to observe this change. In studies that have intensified in recent years, it has been revealed that global climate change is changing the species composition of the ecosystem faster. In this context, we have selected a transition zone for our coniferous forests and some abiotic factors that influence this transition such as temperature, humidity, altitude, and wind speed were discussed in our study. We have tried to understand the role of these abiotic factors in the diversity and abundance of bark beetles, which have destructive impacts on trees. The results presented in this study, demonstrate black pine is associated with a 
high diversity of beetles while brutian pine is correlated high abundance of Scolytinae. These preliminary results suggest that the pine sites do not harbor the scolytine diversity expected for the native habitat. Temperature and humidity are strongly correlated with the species occurrence. In addition, $O$. erosus and $P$. pennidens showed a strong positive correlation with temperature whereas I. sexdentatus showed a positive correlation with altitude. Although it is difficult to isolate the effects of these factors in a transition zone, our data indicate that these abiotic factors affect the composition and the number of bark beetles. Additional studies outside the transition zones of coniferous forests will help us better understand the diversity and damage levels of these insects.

Acknowledgements. We would like to thank Balıkesir Regional Directorate of Forestry (Turkey) for support. We are also grateful to Mustafa Baydemir for his assistance in the fieldwork. This study was funded by Istanbul University - Cerrahpaşa, Scientific Research Project (project 40216).

\section{REFERENCES}

[1] Anonymus (2006): Our Forest Wealth. - T.C. Ministry of Environment and Forests, General Directorate of Forests, Ankara.

[2] Benisch, C. (2007): Kerbtier.de: Beetle fauna of Germany. - https://www.kerbtier.de/.

[3] Bright, D. E. J., Stark, R. W. (1973): The Bark and Ambrosia Beetles of California (Coleoptera: Scolytidae and Platypodidae). - University of California Press.

[4] Brockerhoff, E. G., Jactel, H., Parrotta, J. A., Quine, C. P., Sayer, J. (2008): Plantation forests and biodiversity: oxymoron or opportunity? - Biodiversity and Conservation 17(5): 925-951. doi: 10.1007/s10531-008-9380-x.

[5] Byers, J. A. (2000): Wind-aided dispersal of simulated bark beetles flying through forests. - Ecological Modelling 125: 241-243. doi: 10.1016/S0304-3800(99)00187-8.

[6] Chung, A. Y. C., Chey, V. K., Eggleton, P., Hammond, P. M., Speight, M. R. (2001): Variation in beetle (Coleoptera) diversity at different heights of tree canopy in a native forest and forest plantation in Sabah, Malaysia. - Journal of Tropical Forest Science 13(2): 369-385.

[7] Cochran, P. H., Barrett, J. W. (1998): Thirty-five-year Growth of Thinned and Unthinned Ponderosa Pine in the Methow Valley of Northern Washington. - Portland, OR.

[8] Cole, D. M., McGregor, M. D. (1988): Stand Culture/Bark Beetle Relationships of Immature Tree Stands in the Inland Mountain West. - Ogden, UT.

[9] Doğukan, H., Baran, Ş., Yorulmaz, H., Yenici, E. (2008): Province Environmental Situation Report. - T.C. Ministry of Environment and Urban, Provincial Directorate of Environment and Urban Planning Balıkesir, Çanakkale.

[10] Dönmez, H. (2006): Scolytidae (Coleoptera) Species with Important Parasites and Predators to Determination Harmful on the Conifer Forest in Mersin Regional Forest Directoate. - Master of Science, Gazi University.

[11] Efe, R. (1999): The Physical Factors Affecting Soil Formation and Porperties of the Soils in the Western Part of the Southern Marmara Sub-region. - Turkish Geographical Review 34: 193-209.

[12] ESRI. (2014): ArcGIS for Desktop, version 10.2.2. - Environmental Systems Research Institute. Redlands, CA, USA.

[13] FAO. (2020): FAO Soils Portal. - http://www.fao.org/soils-portal/en/.

[14] Feinsinger, P. (2001): Designing Field Studies for Biodiversity Conservation. - Island Press, Washington, USA.

[15] Fettig, C. J., Klepzig, K. D., Billings, R. F., Munson, A. S., Nebeker, T. E., Negrón, J. F., Nowak, J. T. (2007): The effectiveness of vegetation management practices for 
prevention and control of bark beetle infestations in coniferous forests of the western and southern United States. - Forest Ecology and Management 238(1-3): 24-53.

doi: 10.1016/j.foreco.2006.10.011.

[16] Fiddler, G. O., Hart, D. R., Fiddler, T. A., McDonald, P. M. (1989): Thinning Decreases Mortality and Increases Growth of Ponderosa Pine in Northeastern California. - Pacific Southwest Forest and Range Experiment Station Berkeley, CA.

[17] Foit, J. (2015): Bark- and wood-boring beetles on Scots pine logging residues from final felling: effects of felling date, deposition location and diameter of logging residues. Annals of Forest Research 58(1). doi: 10.15287/afr.2015.302.

[18] Franklin, A. J., Grégoire, J.-C. (1999): Flight behaviour of Ips typographus L. (Col., Scolytidae) in an environment without pheromones. - Annals of Forest Science 56(7): 591-598. doi: 10.1051/forest:19990706.

[19] Gregoire, J.-C., Piel, F., De Proft, M., Gilbert, M. (2001): Spatial Distribution of Ambrosia-Beetle Catches: A Possibly Useful Knowledge to Improve Mass-Trapping. Integrated Pest Management Reviews 6: 237-242. doi: 10.1023/A:1025723402355.

[20] Grégoire, J.-C., Evans, H. F. (2004): Damage and Control of Bawbilt Organisms an Overview. - In: Lieutier, F., Day, K. R., Battisti, A., Grégoire, J.-C., Evans, H. F. (eds.) Bark and Wood Boring Insects in Living Trees in Europe, a Synthesis. Springer, The Netherlands.

[21] Grüne, V. S. (1979): Handbuch zur Bestimmung der europaischen Borkenkafer - Brief Illustrated Key to European Bark Beetles. - Verlag M. \& H. Schaper Hannover, Deutschland.

[22] Hammer, Ø., Harper, D. A. T., Ryan, P. D. (2001): PAST: Paleontological Statistics Software Package For Education And Data Analysis. - Palaeontologia Electronica 4(1): 9.

[23] Heliövaara, K., Peltonen, M. (1999): Bark beetles in a changing environment. Ecological Bulletins 47: 48-53.

[24] Hlásny, T., Krokene, P., Liebhold, A., Montagné-Huck, C., Müller, J., Qin, H., Raffa, K., Schelhaas, M.-J., Seidl, R., Svoboda, M., Viiri, H. (2019): Living with bark beetles: impacts, outlook and management options. - European Forest Institute.

[25] Hulcr, J., Beaver, R. A., Puranasakul, W., Dole, S. A., Sonthichai, S. (2008): A comparison of bark and ambrosia beetle communities in two forest types in northern Thailand (Coleoptera: Curculionidae: Scolytinae and Platypodinae). - Environ Entomol 37(6): 1461-1470. doi: 10.1603/0046-225x-37.6.1461.

[26] İbiş, H. M., Sarıkaya, O. (2012): Bark Beetle Species Diversity in Brutian Pine (Pinus brutia Ten.) Forests of İzmir Province in Turkey. - In Forestry science and practice for the purpose of sustainable development of forestry 20 years of the Faculty of forestry in Banja Luka 1st - 4th November 2012, Republice of Srpska, pp. 533-543.

[27] Jactel, H. (1991): Dispersal and flight behaviour of lps sexdentatus (Coleoptera: Scolytidae) in pine forest. - Annales des Sciences Forestières 48(4): 417-428. doi: 10.1051/forest:19910405.

[28] Jactel, H., Brockerhoff, E. G. (2007): Tree diversity reduces herbivory by forest insects. Ecology Letters 10: 835-848.

[29] Jakus, R. (1998): Patch level variation on bark beetle attack (Col., Scolytidae) on snapped and uprooted trees in Norway spruce primeval natural forest in endemic conditions: species distribution. - Journal of Applied Entomology 122(2-3): 65-76. doi: 10.1111/j.1439-0418.1998.tb01521.x.

[30] Jenkins, M. J., Hebertson, E., Page, W., Jorgensen, C. A. (2008): Bark beetles, fuels, fires and implications for forest management in the Intermountain West. - Forest Ecology and Management 254(1): 16-34. doi: 10.1016/j.foreco.2007.09.045.

[31] Jones, K. L., Shegelski, V. A., Marculis, N. G., Wijerathna, A. N., Evenden, M. L. (2019): Factors influencing dispersal by flight in bark beetles (Coleoptera: Curculionidae: 
Scolytinae): from genes to landscapes. - Canadian Journal of Forest Research 49: 10211041. doi: $10.1139 /$ cjfr-2018-0304.

[32] Jordal, B. H., Knízek, M. (2007): Resurrection of Crypturgus subcribrosus Eggers 1933 stat. n., and its close phylogenetic relationship to Nearctic Crypturgus (Coleoptera, Scolytinae). - Zootaxa 1606: 41-50. doi: 10.11646/zootaxa.1606.1.3.

[33] Kalapanida-Kantartzi, M., Milonas, D. N., Buchelos, C. T., Avtsiz, D. N. (2010): How does pollution affect insect diversity. A study on bark beetle entomofauna of two pine forests in Greece. - Journal of Biological Research-Thessaloniki 13: 67-74.

[34] Karagöz, G., Demirci, M. (2015): Forest Wealth of Turkey. - T.C. Ministry of Forest and Water, General Directorate of Forests, Ankara.

[35] Klutsch, J. G., Negrón, J. F., Costello, S. L., Rhoades, C. C., West, D. R., Popp, J., Caissie, R. (2009): Stand characteristics and downed woody debris accumulations associated with a mountain pine beetle (Dendroctonus ponderosae Hopkins) outbreak in Colorado. - Forest Ecology and Management 258(5): 641-649.

doi: 10.1016/j.foreco.2009.04.034.

[36] Koricheva, J., Vehviläinen, H., Riihimäki, J., Ruohomäki, K., Kaitaniemi, P., Ranta, H. (2006): Diversification of tree stands as a means to manage pests and diseases in boreal forests: myth or reality? - Canadian Journal of Forest Research 36(2): 324-336. doi: $10.1139 / \mathrm{x} 05-172$.

[37] Koštál, V., Doležal, P., Rozsypal, J., Moravcová, M., Zahradníčkov, H., Šimek, P. (2011): Physiological and biochemical analysis of overwintering and cold tolerance in two Central European populations of the spruce bark beetle, Ips typographus. - Journal of Insect Physiology 57: 1136-1146. doi: 10.1016/j.jinsphys.2011.03.011.

[38] Kuhnholz, S., Borden, J. H., Uzunovic, A. (2001): Secondary ambrosia beetles in apparently healthy trees: Adaptations, potential causes and suggested research. Integrated Pest Management Reviews 6: 209-219. doi: 10.1023/A:1025702930580.

[39] Kurz, W. A., Dymond, C. C., Stinson, G., Rampley, G. J., Neilson, E. T., Carroll, A. L., Ebata, T., Safranyik, L. (2008): Mountain pine beetle and forest carbon feedback to climate change. - Nature 452(7190): 987-990. doi: 10.1038/nature06777.

[40] Lieutier, F., Mendel, Z., Faccoli, M. (2016): Bark Beetles of Mediterranean Conifers. In: Paine, T. D., Lieutier, F. (eds.) Insects and Diseases of Mediterranean Forest, Springer, Switzerland.

[41] Lindgren, B. S., Raffa, K. F. (2013): Evolution of tree killing in bark beetles (Coleoptera: Curculionidae): trade-offs between the maddening crowds and a sticky situation. - The Canadian Entomologist 145(05): 471-495. doi: 10.4039/tce.2013.27.

[42] Lompe, A. (2002): Käfer Europas. - http://www.coleo-net.de/coleo/index.htm.

[43] Marini, L., Lindelöw, Å., Jönsson, A. M., Wulff, S., Schroeder, L. M. (2013): Population dynamics of the spruce bark beetle: a long-term study. - Oikos 122: 1768-1776. doi: 10.1111/j.1600-0706.2013.00431.x.

[44] Mendel, Z., Halperin, J. (1982): The Biology and Behavior of Orthotomicus erosus in Israel. - Phytoparasitica 10(3): 169-181.

[45] Mendel, Z. (1983): Seasonal history of Orthotomicus erosus (Coleoptera: Scolytidae) in Israel. - Phytoparasitica 11(1): 13-24.

[46] Moraes, R. C. B., Haddad, M. L., Silveira Neto, S., Reyes, A. E. L. (2003): Software para análise faunística-ANAFAU. - In: Pedro, S. (ed.) Simpósio de controle biológico 8: 195.

[47] Mullen, K., O’Halloran, J., Breen, J., Giller, P., Pithon, J., Kelly, T. (2008): Distribution and composition of carabid beetle (Coleoptera, Carabidae) communities across the plantation forest cycle - Implications for management. - Forest Ecology and Management 256: 624-632. doi: 10.1016/j.foreco.2008.05.005.

[48] Ogden, A. E. (2008): Forest management in a changing climate: building the environmental information base for southwest Yukon. - The Forestry Chronicle 83(6): 806-809. doi: 10.5558/tfc83806-6. 
[49] Økland, B., Bjørnstad, O. N. (2006): A Resource-Depletion Model of Forest Insect Outbreaks. - Ecology 87(2): 283-290. doi: 10.1890/05-0135.

[50] Özcan, G. E., Eroğlu, M., Alkan-Akıncı, H. (2011): Use of pheromone-baited traps for monitoring Ips sexdentatus (Boerner) (Coleoptera: Curculionidae) in oriental spruce stands. - African Journal of Biotechnology 10(72): 16351-16380.

[51] Özkazanç, O., İktüeren, Ş. I., Yücel, M. (1985): Studies on Biology and Control of Orthotomicus erosus (Woll.) in Mediterranenan and Aegean Regions. - Forestry Research Institute Publications, Technical Bulletin Series.

[52] Peltonen, M., Heliövaara, K., Väisänen, R., Keronen, J. (1998): Bark beetle diversity at different spatial scales. - Ecography 21(5): 510-517. doi: 10.1111/j.1600-0587.1998.tb00442.x.

[53] Peltonen, M., Heliövaara, K. (1999): Attack density and breeding success of bark beetles (Coleoptera, Scolytidae) at different distances from forest-clearcut edge. - Agricultural and Forest Entomology 1: 237-242. doi: 10.1046/j.1461-9563.1999.00033.x.

[54] Pielou, E. C. (1969): An introduction to mathematical ecology. - Wiley Interscience, New York.

[55] Raffa, K. F., Gregoire, J. C., Lindgren, B. S. (2015): Natural History and Ecology of Bark Beetles. - In: Vega, F. E., Hofstetter, R. W. (eds.) Bark Beetles Biology and Ecology of Native and Invasive Species. Elsevier, USA.

[56] Rodrigez, S. C., Cognato, A. I., Righi, C. A. (2017): Bark and Ambrosia Beetle (Curculionidae: Scolytinae) Diversity Found in Agricultural and Fragmented Forests in Piracicaba-SP, Brazil. - Environmental Entomology 46(6): 1254-1263.

[57] Rosenzweig, M. L. (1995): Species diversity in time and space. - Cambridge University Press, Cambridge, United Kingdom.

[58] Rubin-Aguirre, A., Saenz- Romero, C., Lindig-Cisneros, R., del-Rio-Mora, A. A., TenaMorelos, C. A., Campos-Bolaños, R., del-Val, E. (2015): Bark beetle pests in an altitudinal gradient of a Mexican managed forest. - Forest Ecology and Management 343: 73-79. doi: 10.1016/j.foreco.2015.01.028.

[59] Sarıkaya, O., Avc1, M. (2011): Bark beetle fauna (Coleoptera: Scolytinae) of the coniferous forests in the Mediterrenean region of WesternTurkey, with a new record for Turkish fauna. - Turkish Journal of Zoology 35(1): 33-47. doi: 10.3906/zoo-0901-8.

[60] Sarıkaya, O., Yıldırım, S. (2011): Scolytinae (Coleoptera: Curculionidae) Species of the Coniferous Forests in Isparta-Aksu Province. - Journal of Bartin Faculty of Forestry 13(20): 38-50.

[61] Sarıkaya, O., İbiş, H. M., Toprak, Ö. (2013): The flight activity and population density of Orthotomicus erosus (Wollaston, 1857) in the Brutian pine (Pinus brutia Ten.) forests of İzmir Province, Turkey. - International Journal of Sciences: Basic and Applied Research 12(1): 208-219.

[62] Sauvard, D. (2004): General Biology of Bark Beetles. - In: Lieutier, F., Day, K. R., Battisti, A., Gregoire, J. C., Evans, H. F. (eds.) Bark and Wood Boring Insects in Living Trees in Europe, a Synthesis. Springer, The Netherlands.

[63] Selmi, E. (1998): Türkiye Kabuk Böcekleri ve Savaşı. - İstanbul University Press, İstanbul.

[64] Spellerberg, I. F., Fedor, P. J. (2003): A tribute to Claude Shannon (1916-2001) and a plea for more rigorous use of species richness, species diversity and the 'ShannonWiener' Index. - Global Ecology \& Biogeography 12: 177-179.

[65] Tribe, G. D. (1992): Colonisation sites on Pinus radiata logs of the bark beetles, Orthotomicus erosus, Hylastes angustatus and Hylurgus ligniperda (Coleoptera: Scolytidae). - Journal of the Entomological Society of Southern Africa 55(1): 77-84.

[66] TSMS. (1998): Turkish State Meteorological Service. - https://www.mgm.gov.tr.

[67] Vasconcelos, T., Nazaré, N., Branco, M., Kerdelhue, C., Sauvard, D., Lieutier, F. (2003): Host Preference of Tomicus piniperda and Tomicus destruens for Three Pine Species. - 
In: Kamata, N., Liebhold, A. M., Quiring, D. T., Clancy, K. M. (eds.) Forest Insect Population Dynamics and Host Influences. IUFRO Kanazawa, Japan, pp. 19-21.

[68] Weslien, J., Schroeder, L. M. (1999): Population levels of bark beetles and associated insects in managed and unmanaged spruce stands. - Forest Ecology and Management 115: 267-275. doi: 10.1016/S0378-1127(98)00405-8.

[69] Williams, D. T., Straw, N., Fielding, N., Jukes, M., Price, J. (2017): The influence of forest management systems on the abundance and diversity of bark beetles (Coleoptera: Curculionidae: Scolytinae) in commercial plantations of Sitka spruce. - Forest Ecology and Management 398: 196-207. doi: 10.1016/j.foreco.2017.05.014.

[70] Wood, S. L. (1982): Great Basin Naturalist Memoirs the Bark and Ambrosia Beetles of North and Central America (Coleoptera: Scolytidae), a Taxonomic Monograph. Brigham Young University, Provo, Utah.

[71] Wood, S. L., Bright, D. E. (1992): A Catolog of Scoltyidae and Platypodidae (Coloeptera), Part II: Taxonomic Index Volume A. - Great Basin naturalist memoirs.

[72] Y1ldı, Y. (2012): The Scolytidae Fauna of Bartın and Karabük Forest and Determination of Some Important Species Biology. - Doctor of Philosophy, Bartın University.

[73] Zhang, X., Zhao, G., Zhang, X., Li, X., Yu, Z., Liu, Y., Liang, H. (2017): Ground Beetle (Coleoptera: Carabidae) Diversity and Body-Size Variation in Four Land Use Types in a Mountainous Area Near Beijing, China. - The Coleopterists Bulletin 71(2). doi: 10.1649/0010-065x-71.2.402.

[74] Zou, Y., Feng, J., Xue, D., Sang, W., Axmacher, J. (2011): Insect Diversity: Addressing an Important but Strongly Neglected Research Topic in China. - Journal of Resources and Ecology 2(4): 380-384. doi: 10.3969/j.issn.1674-764x.2011.04.013. 